\title{
HUBUNGAN KEDEWASAAN MAHASISWA FAKULTAS KEDOKTERAN PROGRAM STUDI KEDOKTERAN UMUM ANGKATAN 2012 UNIVERSITAS SAM RATULANGI TERHADAP CARA BERSOSIALISASI
}

\author{
${ }^{1}$ Citra F. Karim \\ ${ }^{2}$ Jehosua S.V. Sinolungan \\ ${ }^{2}$ Henry Opod \\ ${ }^{1}$ Kandidat Skripsi Fakultas Kedokteran Universitas Sam Ratulangi Manado \\ ${ }^{2}$ Bagian Psikologi Universitas Sam Ratulangi Manado \\ Email: citrakarim_09012@yahoo.com
}

\begin{abstract}
In general, maturity means a state of a person releted to his/her physical, mental, social, emotional, spiritual, and moral development. Humanbeings are social creatures for the whole periods of lives. This study aimed to find out the relationship between the maturity of students of Faculty of Medicine, University of Sam Ratulangi Manado 2012 and their socialization. This was an analytic study with stratified random sampling design. Data were collected by using questionairres. There were 47 respondents, consisted of 16 male and 31 female students. Data were analyzed by using Pearson - product moment correlation test. The results showed that 47 respondents (97.9\%) had good maturity and one respondent (2.1\%) fair maturity. About their socialization, six respondents (12.8\%) were categorized as good; 39 respondents (83\%) fair; and two respondents (4.3\%) bad. Correlation test showed $r=-0.116$ and $P=0.219$. Conclusion: there were no relationship between maturity and socialization among students of Faculty of Medicine, University of Sam Ratulangi Manado 2012.

Keywords: maturity, socialization, students
\end{abstract}

\begin{abstract}
Abstrak: Kedewasaan adalah status seseorang yang telah memiliki kematangan baik secara fisik, kemampuan mental, pertumbuhan sosial, emosi, serta pertumbuhan spiritual dan moral. Pada dasarnya sosialisasi dialami oleh individu sebagai makhluk sosial sepanjang kehidupannya sejak dilahirkan sampai meninggal dunia. Penelitian ini bertujuan untuk mengetahui ada tidaknya hubungan antara kedewasaan mahasiswa Fakultas Kedokteran Universitas Sam Ratulangi Manado angkatan 2012 dan cara bersosialisasi. Jenis penelitian ini bersifat analitik dengan teknik pengambilan sampel stratified random sampling. Metode pengumpulan data dengan menggunakan kuesioner. Penelitian dilakukan pada 47 responden, terdiri dari 16 laki-laki dan 31 perempuan. Analisis data menggunakan uji statistik yaitu uji korelasi Pearson - product moment. Hasil penelitian memperlihatkan jumlah mahasiswa yang memiliki kedewasaan baik sebanyak 46 responden $(97,9 \%)$ dan satu responden $(2,1 \%)$ cukup. Jumlah mahasiswa yang memiliki sosialisasi kategori baik sebanyak enam responden (12,8\%), kategori cukup 39 responden (83\%), serta dua responden (4,3\%) kurang. Berdasarkan uji korelasi Pearson-product moment didapatkan $r=-0,116$ dengan $P=0,219$. Simpulan: pada mahasiswa Fakultas Kedokteran Unsrat angkatan 2012 tidak terdapat hubungan antara kedewasaan dan sosialisasi
\end{abstract}

Kata kunci : kedewasaan, sosialisasi, mahasiswa 
Kedewasaan sangat erat keterkaitannya dengan sikap kepribadian seseorang, antara lain: tingkahlaku, pola pikir, kecerdasan intelektualitas, kecerdasan emosi, dan kecerdasan spritual.

Dalam pergaulan sehari-hari, kita sering mendengar begitu banyak orang yang sering mengatakan kepada orang lain, jika orang tersebut tidak memperlihatkan perilaku yang baik, selalu diidentikkan dengan orang tersebut tidak atau belum dewasa atau tidak ada atau tidak tahu etiket.

Menurut Uno M.R. (2010) etiket berasal dari bahasa Prancis "etiquette" yang berarti aturan sopan santun dan tata cara pergaulan yang baik antara sesama manusia. Biasanya orang yang mengerti dan menghayati etiket akan lebih berhasil dalam pergaulan dan pekerjaan. Etika yang dijumput dari bahasa Latin, "ethica”, merupakan falsafah moral dan pedoman cara hidup yang benar dilhat dari agama, sudut budaya dan susila. Etiket adalah perangkat operasional sehari-hari yang didasari oleh etika. ${ }^{1}$

Menurut Hurlock masa dewasa dibagi menjadi tiga bagian yaitu masa dewasa awal (masa dewasa dini/ young adult), masa dewasa madya (middle adulthood) dan masa dewasa lanjut. Masa dewasa awal adalah masa pencaharian kemantapan dan masa reproduktif yaitu suatu masa yang penuh dengan masalah dan ketegangan sosial, periode isolasi sosial, periode komitmen dan masa ketergantungan, perubahan nilai-nilai, kreativitas dan penyesuaian diri pada pola hidup yang baru. ${ }^{2,3}$

Papalia, Olds dan Feldman (2001) menyatakan bahwa kelompok dewasa muda (young adulthood) berkisar antara usia 2040 tahun. ${ }^{4}$ Masa perkembangan dewasa muda ditandai dengan keinginan mengaktualisasikan segala ide-pemikiran yang dimatangkan selama mengikuti pendidikan tinggi (universitas/akademi). ${ }^{5}$

Sosialisasi dialami oleh individu sebagai makhluk sosial sepanjang kehidupannya sejak ia dilahirkan sampai meninggal dunia. Karena interaksi merupakan kunci berlangsungnya proses sosialisasi maka diperlukan agen sosialisasi, yakni orang- orang di sekitar individu tersebut yang mentransmisikan nilai-nilai atau normanorma tertentu baik secara langsung maupun tidak langsung. ${ }^{6}$

Sifat kedewasaan seseorang dapat dilihat dari pertumbuhan sosialnya. Pertumbuhan sosial adalah suatu pemahaman tentang bagaimana dia menyayangi pergaulan, bagaimana dia dapat memahami tentang bagaimana watak dan kepribadian seseorang, dan cara dia mampu membuat agar dirinya disukai oleh orang lain dalam pergaulannya. $^{3}$

\section{METODE}

Jenis penelitian ini adalah korelasi analitik dengan menggunakan metode kuantitatif. Tempat penelitian dilakukan di Fakultas Kedokteran Universitas Sam Ratulangi Manado pada bulan OktoberDesember 2012. Jumlah sampel pada penelitian ini adalah sebanyak 47 responden. Data diambil dengan cara kuesioner. Data yang didapatkan pada penelitian dianalisis dengan menggunakan korelasi Pearsonproduct moment.

\section{HASIL}

Deskripsi responden penelitian disajikan dalam bentuk tabel sebagai berikut:

Berdasarkan tabel 1. Distribusi responden berdasarkan usia dapat diketahui bahwa sebanyak $87,2 \%$ (41 responden) berusia 18 tahun, 8,5\% (4 responden) berusia 19 tahun, dan 4,3\% (2 responden) berusia 20 tahun.

Tabel 1. Distribusi responden berdasarkan usia.

\begin{tabular}{ccc}
\hline Usia & Responden & $\begin{array}{c}\text { Persentase } \\
(\mathbf{\%})\end{array}$ \\
\hline 18 tahun & 41 & 87,2 \\
19 tahun & 4 & 8,5 \\
20 tahun & 2 & 4,3 \\
\hline Total & 47 & 100 \\
\hline
\end{tabular}

Berdasarkan tabel 2. Distribusi responden berdasarkan jenis kelamin yaitu 
laki-laki 34\% (16 responden) dan perempuan $66 \%$ (31 responden).

Tabel 2. Distribusi responden berdasarkan jenis kelamin.

\begin{tabular}{ccc}
\hline $\begin{array}{c}\text { Jenis } \\
\text { Kelamin }\end{array}$ & Responden & $\begin{array}{c}\text { Persentase } \\
\mathbf{( \% )}\end{array}$ \\
\hline Laki - laki & 16 & 34 \\
Perempuan & 31 & 66 \\
\hline Total & 47 & 100 \\
\hline
\end{tabular}

Tabel 3. Hasil uji korelasi.

\begin{tabular}{ccc}
\hline & Korelasi & \\
\hline \multirow{3}{*}{ Kedewasaaan } & Pearson & Bersosialisasi \\
& Correlation & -.116 \\
& Sig. (1-tailed) & .219 \\
& $\mathrm{~N}$ & 47 \\
\hline
\end{tabular}

Tujuan utama dari penelitian ini yaitu untuk melihat hubungan kedewasaan mahasiswa fakultas kedokteran program studi kedokteran umum angkatan 2012 dengan sosialisasi. Metode korelasi yang dipilih untuk menghitung koefisien korelasi tersebut yaitu dengan menggunakan korelasi Pearson-product moment pada aplikasi SPSS statistics version 20. Hasil perhitungan korelasi pada SPSS antara kedewasaan dan sosialisasi dapat dilihat pada tabel 3 .

\section{BAHASAN}

Berdasarkan hasil penelitian diatas dimana didapatkan $\mathrm{r}=-0,116$ dengan $\quad P=$ $0,219>\alpha=0,05$ secara statistik tidak bermakna. Dengan demikian hipotesis yang diterima yaitu Ho dimana tidak terdapat hubungan antara kedewasaan dengan sosialisasi pada mahasiswa angkatan 2012, dan secara otomatis $\mathrm{H}_{1}$ ditolak. Berikut ini akan dibahas apa saja yang mendukung hingga tidak terdapatnya hubungan antara kedewasaan dan sosialisasi.

\section{Situasi sosial}

Situasi sosial, memberi bentuk tingkah laku terhadap individu yang berada dalam situasi tersebut. ${ }^{7}$ Berdasarkan hal tersebut dapat dijelaskan bahwa seseorang yang berada dalam situasi tertentu dapat menyesuaikan diri terhadap situasi yang ada. Tidak hanya orang dewasa yang dapat menyesuaikan diri ketika berinteraksi, siapa pun itu bisa melakukannya dan akan terbentuk pola interaksi dimana tiap individu akan dapat meyesuaikan diri terhadap situasi yang dihadapi.

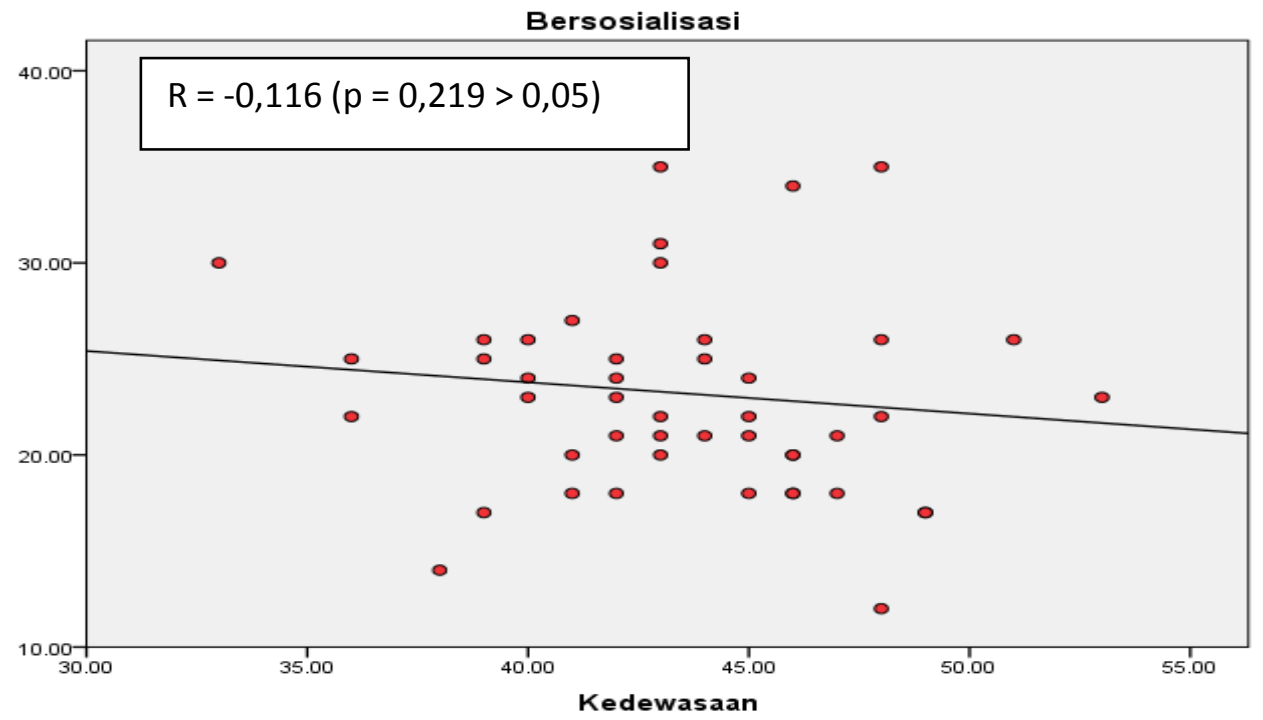

Gambar 1. Scatterplot skor kedewasaan dan bersosialisasi mahasiswa. 


\section{Tujuan pribadi masing-masing individu}

Ada tujuan kepribadian yang dimiliki masing-masing individu sehingga berpengaruh terhadap pelakunya. Misalnya, dalam setiap interaksi individu pasti memiliki tujuan. ${ }^{7}$ Berdasarkan hal tersebut dapat dikatakan bahwa seseorang akan memberikan pola interaksi sosial yang berbeda, dimana setiap individu memiliki tujuan pribadi masing-masing sehingga kedewasaan tidak mempengaruhi terhadap terjadinya suatu interaksi.

\section{Penafsiran situasi}

Ada penafsiran situasi, bahwa setiap situasi mengandung arti bagi setiap individu sehingga mempengaruhi individu untuk melihat dan menafsirkan situasi tersebut. ${ }^{7}$

Semua orang bisa menafsirkan segala sesuatu situasi yang terjadi dengan sudut pandang yang berbeda. Tidak hanya mereka yang dikategorikan dewasa awal yang bisa menafsirkan situasi yang terjadi.

\section{Lingkungan}

Lingkungan yang dimaksud adalah kondisi sekitar individu baik lingkungan alam, kebudayaan, dan masyarakat yang dapat mempengaruhi proses sosialisasi. Kondisi lingkungan sekitar tidak menentukan, tetapi mampu mempengaruhi dan membatasi proses sosialisasi seseorang. ${ }^{8}$

\section{Motivasi}

Dalam menjalani kehidupan, setiap individu mempunyai motivasi-motivasi untuk menjadikan hidupnya lebih berarti. Motivasi merupakan kekuatan dalam diri seseorang yang menggerakkan seseorang untuk berbuat sesuatu. Motivasi yang dimiliki seseorang mampu mempengaruhi orang tersebut dalam bersosialisasi. Orang yang mempunyai motivasi besar dalam bersosialisasi tentu berbeda apabila dibandingkan dengan seseorang yang tidak mempunyai motivasi. ${ }^{8}$

\section{Sifat dasar}

Sifat dasar seseorang meliputi karakter, watak, serta sifat emosional. Sifat dasar merupakan warisan dari ayah dan ibu yang diturunkan melalui gen. ${ }^{8}$

\section{Perbedaan perorangan}

Setelah lahir, seorang anak akan tumbuh dewasa dengan karakteristiknya sendiri-sendiri. Setiap anak mempunyai karakteristik yang berbeda-beda, seperti ciri fisik (bentuk badan, warna kulit, warna mata, dan bentuk rambut), ciri-ciri normal, emosional, personal, dan sosial. Perbedaan perorangan ini mampu mempengaruhi sosialisasi seseorang. ${ }^{8}$

\section{SIMPULAN DAN SARAN}

Tidak terdapat hubungan yag bermakna antara kedewasaan mahasiswa program studi kedokteran umum angkatan 2012 dengan atau terhadap cara bersosialisasi.

Diperlukan penelitian lanjutan untuk menilai kedewasaan dan sosialisasi berdasarkan jenis kelamin lalu melihat apakah jenis kelamin dapat mempunyai peranan yang penting terhadap tinggi rendahnya kedewasaan atau sosialisasi.

\section{DAFTAR PUSTAKA}

1. Uno MR. Buku Pintar Etiket Untuk Remaja. Jakarta: PT. Gramedia Pustaka Utama, 2010.

2. Silitonga Ferry. Arti kedewasaan [homepage on the Internet] 2010. Nodate [cited 2012 Oct 19]. Available from: http://m.kompasiana.com/post/edukasi/201 0/09/08/arti-kedewasaan/

3. Jahja Y. Psikologi perkembangan. Jakarta: Kencana, 2011.

4. Dariyo A. Perencanaan dan Pemilihan Karir Sebagai Seorang Guru/Dosen Pada Dewasa Muda. Jurnal Provitae. 2004;1:56

5. Dariyo A. Psikologi Perkembangan Dewasa Muda. Bandung: Grafindo Media Pratama, 2008. 
6. Ihromi TO. Bunga Rampai Sosiologi Keluarga. Jakarta: Yayasan Obor Indonesia, 1999.

7. Faktor-faktor yang mempengaruhi interaksi sosial [homepage on the Internet]. Nodate [cited 2013 Jan]. Available from: http://www.psychologymania.com/2012/11

/faktor-faktor-yang-mempengaruhi.html

8. Waluyo, Suwardi, Feryanto A, Haryanto T. Ilmu Pengetahuan Sosial Untuk SMP/MTs Kelas VII. Jakarta: Pusat Perbukuan, Departemen Pendidikan Nasional, 2008. 